\title{
Parotid Cells and Infrared Laser. A Morphometric Study
}

\author{
Constanza Gatica, ${ }^{1}$ Diego Calfunao, ${ }^{1}$ Valeria Colicheo, ${ }^{1}$ Kurt Buchegger, ${ }^{1}$ Paola Muñoz, ${ }^{1}$ Orlando Garrido, ${ }^{2}$ Roberto Jaramillo, ${ }^{2}$ \\ Ricardo Cornejo ${ }^{1}$
}

'Department of Basic Sciences, School of Medicine, Universidad de La Frontera, Chile

2Instituto de Ciencias Marinas y Limnológicas, Universidad Austral de Chile, Chile

Disclose and conflicts of interest: none to be declared by all authors

\begin{abstract}
Introduction: the parotid glands play a fundamental role in the synthesis and secretion of proteins such as the zymogens of the salivary amylase responsible for the degradation of starches, an important mechanism in the formation of the alimentary bolus, and other protein molecules that accompany the structuring of the saliva, which perform fundamental functions in digestion. In this context, the aim of the present study was to determine morphometric parameters of serous glandular structures subjected to infrared laser stimulation. For this, twelve-month-old Sprague Dawley rats were divided into four groups of 4 animals each: control group and those stimulated with doses of 4,8 and $16 \mathrm{~J} / \mathrm{cm}^{2}$. Once the rats had been euthanized, the respective parotid glands were extracted and processed for optical microscopy, obtaining micrographs on which morphometric studies were conducted. The results showed that the cellular, acinar and nuclear areas increased significantly in the experimental group irradiated with the $16 \mathrm{~J} / \mathrm{cm}^{2}$ dose compared to the control group and the other experimental groups. However, considering the number of zymogen granules, a remarkable reduction in the groups irradiated with 8 and $16 \mathrm{~J} / \mathrm{cm}^{2}$ was observed compared to the control group. The granular area was also altered, evidencing a significant reduction in the $4 \mathrm{and} 8 \mathrm{~J} / \mathrm{cm}^{2}$ experimental groups compared to the control group. By contrast, the $16 \mathrm{~J} / \mathrm{cm}^{2}$ group showed an evident increase in area compared to the other experimental groups. It is clearly demonstrated that the inductions of infrared laser compared to the controls revealed noticeable differences in all the components analyzed, which could provide background on different functionalities in the metabolism of these glands.
\end{abstract}

Keywords: Parotid cells; Morphometry; Infrared laser; Biostimulation.

\section{Introduction}

The major salivary glands share the function of moistening the oral cavity to facilitate processes like chewing, swallowing, phonation and digestion. They are represented in even distribution as submandibular, submaxillary and parotid glands, with the parotid being the largest. ${ }^{1}$ The parotid glands are located in the subcutaneous tissue on each side of the face below and in front of the ears from the zygomatic arch from above, between the sternocleidomastoid and masseter muscles, extending from the mastoid process to just under the angle of the mandible. It communicates with the oral cavity via an excretory duct, the parotid duct, ${ }^{2}$ which projects from the anterior portion of the gland above the masseter muscle, perforating the buccinator muscle on its route to open into a small papilla in the buccal mucosa of the cheek against the maxillary second molar. ${ }^{3}$ The parotid tissue is comprised of serous acinar cells organized in lobes surrounded by fine septa of fibrous connective tissue. In the serous acini, the cells have the shape of a column or truncated pyramid and surround a smaller lumen than that of the mucous acini. ${ }^{4}$ Its apical cytoplasm is full of zymogenous secretory granules containing an electrodense product with a concentrated center, ${ }^{5}$ where the distribution of organelles is typical of the secretory protein cells, as a great development of both the rough endoplasmic reticulum (RER), concentrated mainly in the infranuclear region surrounded by myoepithelial cells, and the Golgi complex and an adequate number of mitochondria surrounding a central or basal nucleus ${ }^{6}$ knowledge of the structures studied is truly important. This study compares the human parotid gland to that of three animal species from a histological point of view. Five parotid gland samples from each animal species were used: Sprague Dawley rats (Rattus norvegicus. Amano et al., also mentions that another distinguishing characteristic of these serous acini is the presence of intercellular secretory canaliculi that penetrate from a third to half the distance between the lumen and the basal lamina. The luminal surface of the serous cells contains small microvilli that extend to the secretory canaliculi. The parotid gland in humans produces between 20 and $30 \%$ of the total saliva, generating a serous secretion accompanied by a certain mucous component. ${ }^{7}$ The saliva secreted by this gland has elevated concentrations of the ptyalin enzyme, salivary amylase or salivary diastase, which responsible for digesting most of the starches, and the secretory IgA, which inactivates antigens located in the buccal cavity. ${ }^{8}$ Therefore, its secretion is vitally 
important for digestive and immunological processes in the oral cavity. The pathologies related to the dysfunction of the salivary glands are associated with several systemic disorders, such as metabolic disorder, autoimmune diseases and even manifests as side effects caused by drugs or radiation therapy. When these are present, they heavily influence oral health, also affecting digestive functions and therefore the patient's quality of life. ${ }^{9}$ In this context, ${ }^{10}$ indicate that the use of a laser in various areas of conventional medicine currently allows for the optimal rehabilitation of patients in treatments related to healing processes, musculoskeletal problems and the healing of fractures. On the other hand, and in particular, it has been recognized for several years how the stimulations emitted by a GaAs laser have been used for therapeutic purposes, promoting anti-inflammatory, analgesic and tissue regeneration processes,$^{11}$ while at cellular level effects have been described, emphasizing protein, DNA and collagen synthesis ${ }^{12-14}$ modulating both cell proliferation and the cytosolic calcium concentration. ${ }^{15,16}$ In this light, the biological effects described by García \& Martínez (2006) are supported in that the energy emitted by the laser is deposited and absorbed by the photoreceptors present in the different cell structures, generating bioelectrical, biochemical, bioenergetic and biostimulating effects. Based on the preceding discussion, the main aim of the present study was to determine the biostimulating effect of increasing doses of the gallium arsenide (GaAs) infrared laser on the morphofunctionality in the parotid gland.

\section{Materials and Methods}

\section{Experimental model}

20 healthy 12-week-old Sprague-Dawley rats were used, which were subjected to infrared laser radiation at different flows ( 0 (control), 4,8 and $\left.16 \mathrm{~J} / \mathrm{cm}^{2}\right)$ for 15 consecutive days. The day after the radiation regime was complete, the animals were euthanized by $\mathrm{CO}_{2}$ overdose according to the guidelines on animal management approved by the respective ethics committee ( $\left.\mathrm{N}^{\circ} 061-18\right)$ (Figure 1).

\section{Processing of histological samples.}

For the study with optical microscopy, the normal parotid glands and those stimulated for 15 consecutive days with different doses of infrared laser were fixed in $2 \%$ glutaraldehyde in phosphate buffer $0,1 \mathrm{M}$ at $\mathrm{Ph} 7,2$ during 2 hours. Then, were washed with $\mathrm{NaCl}$ and sacarose. After that, proceed to dehydration in a series of acetone increasing from 30 to $100 \%$ and then included in Araldite synthetic resin 6005. The resins were incubated at $60^{\circ} \mathrm{C}$ for two days for its complete polymerization. Finally, using a Leica Em UC7 Ultramicrotome, semi-thin sections of between 1.5 and 1 um thickness were obtained, which were stretched with xylol vapors and stained with toluidine blue and some with hematoxylin eosin. The respective histological sections were micrographed at different magnifications, ending with 1000X, using a Carl Zeiss Axioskop 40 microscope with a built-in digital camera. The Image J 1.52 software (Wayne Rasband, NIH, USA) was used to perform the morphometric analyses.

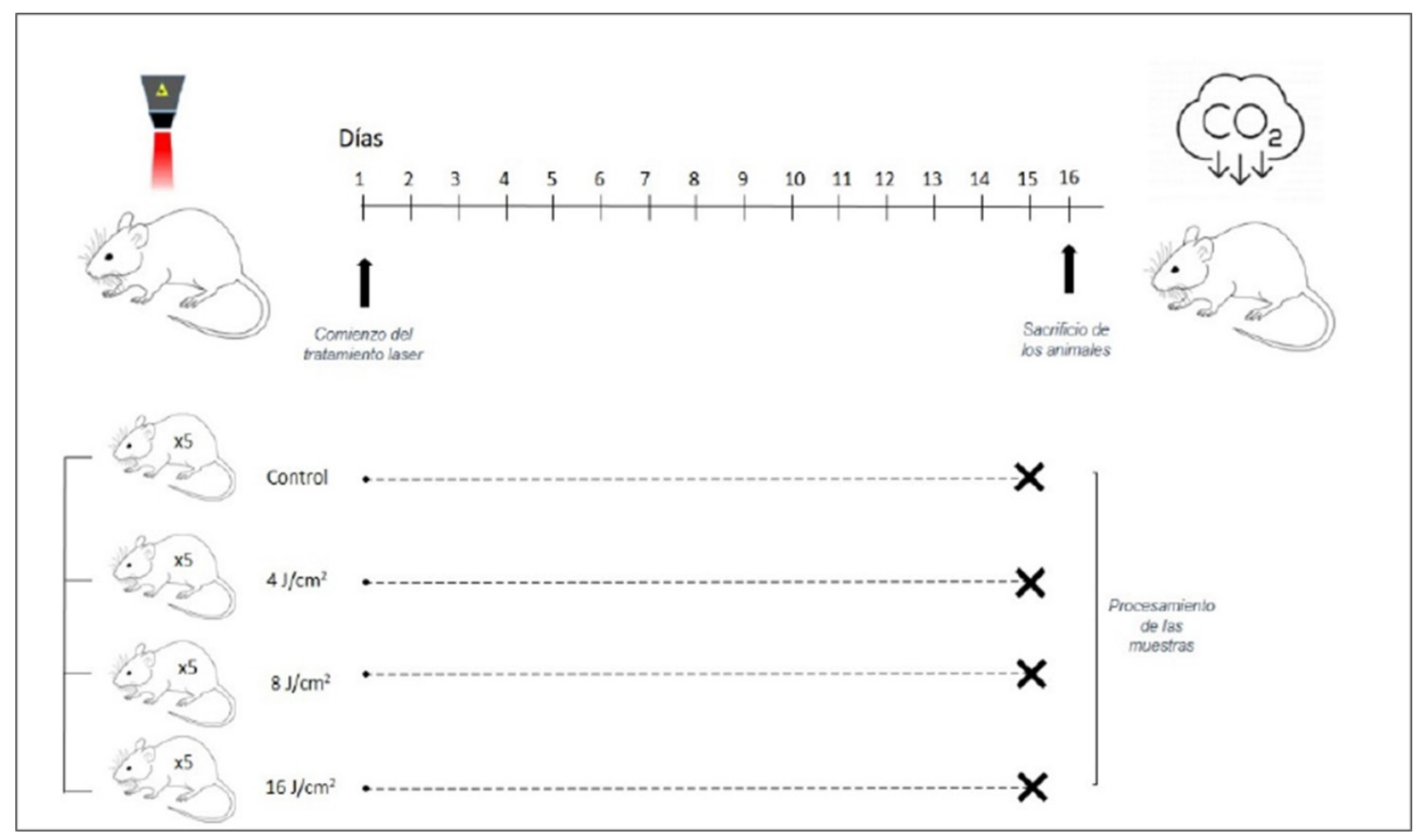

Figure 1. Outline of the experimental model 


\section{Statistical analysis.}

The collected data were plotted using the mean \pm standard deviation. The statistical analysis employed a Kruskal-Wallis test, considering $\mathrm{P}<0.05$ statistically significant.

\section{Results}

The stimulations with infrared laser on cells of rat parotid gland with doses corresponding to 4,8 and $16 \mathrm{~J} / \mathrm{cm}^{2}$ compared to normal cells, represented in Figure 2, showed a relation between increasing doses of infrared laser and variations in the acinar area. Additionally, it was observed that there were larger granules in the samples irradiated with the $16 \mathrm{~J} / \mathrm{cm}^{2}$ dose.

After irradiating rat parotid gland cells with infrared laser with increasing doses corresponding to 4,8 y $16 \mathrm{~J} / \mathrm{cm}^{2}$, results referring to the cellular, acinar, nuclear and granular areas were obtained, as well as their number.
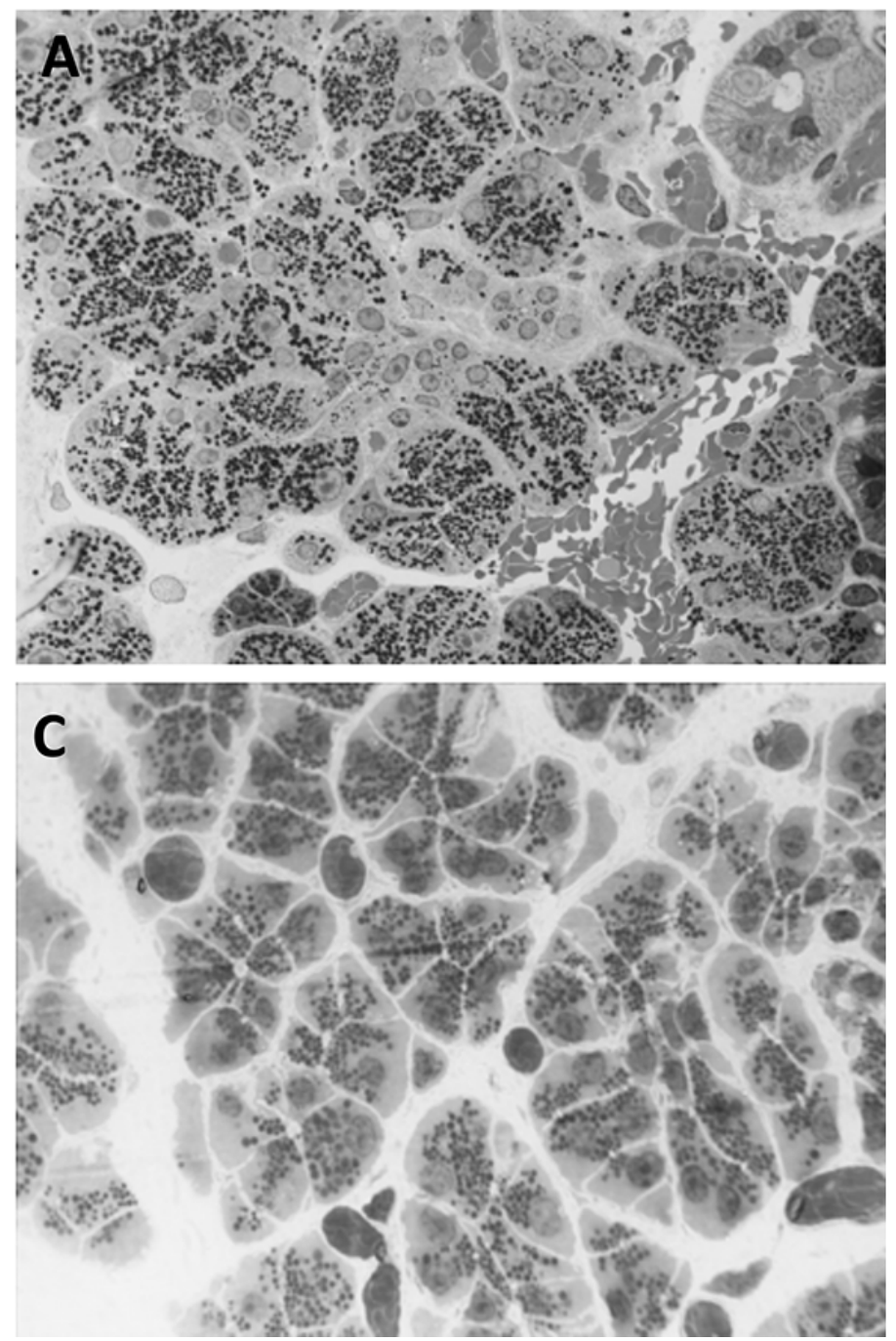

With respect to the cellular area (Figure $3 \mathrm{~A}$ ), and comparing the control group with the group subjected to the $4 \mathrm{~J} / \mathrm{cm}^{2}$ dose, a slight decrease in total cellular area was observed; however, when the dose was increased to $8 \mathrm{~J} / \mathrm{cm}^{2}$, a minimum increase was noted compared to the previous group, but similar to the decrease compared to the control group. However, these differences were not significant. The last group, subjected to the $16 \mathrm{~J} / \mathrm{cm}^{2}$ dose, showed an evident increase in cellular area compared to all the previous groups.

With respect to the acinar area, the data in (Figure 3B) showed that after comparing, to each other, the control group and those irradiated by 4 and $8 \mathrm{~J} / \mathrm{cm}^{2}$, there were no significant differences, which implies that there is a minimal or slight difference between the acinar areas of these groups. However, when comparing these three groups with the $16 \mathrm{~J} / \mathrm{cm}^{2}$ dose, significant differences were observed, with this variation being evidence of a considerable increase in the acinar area.
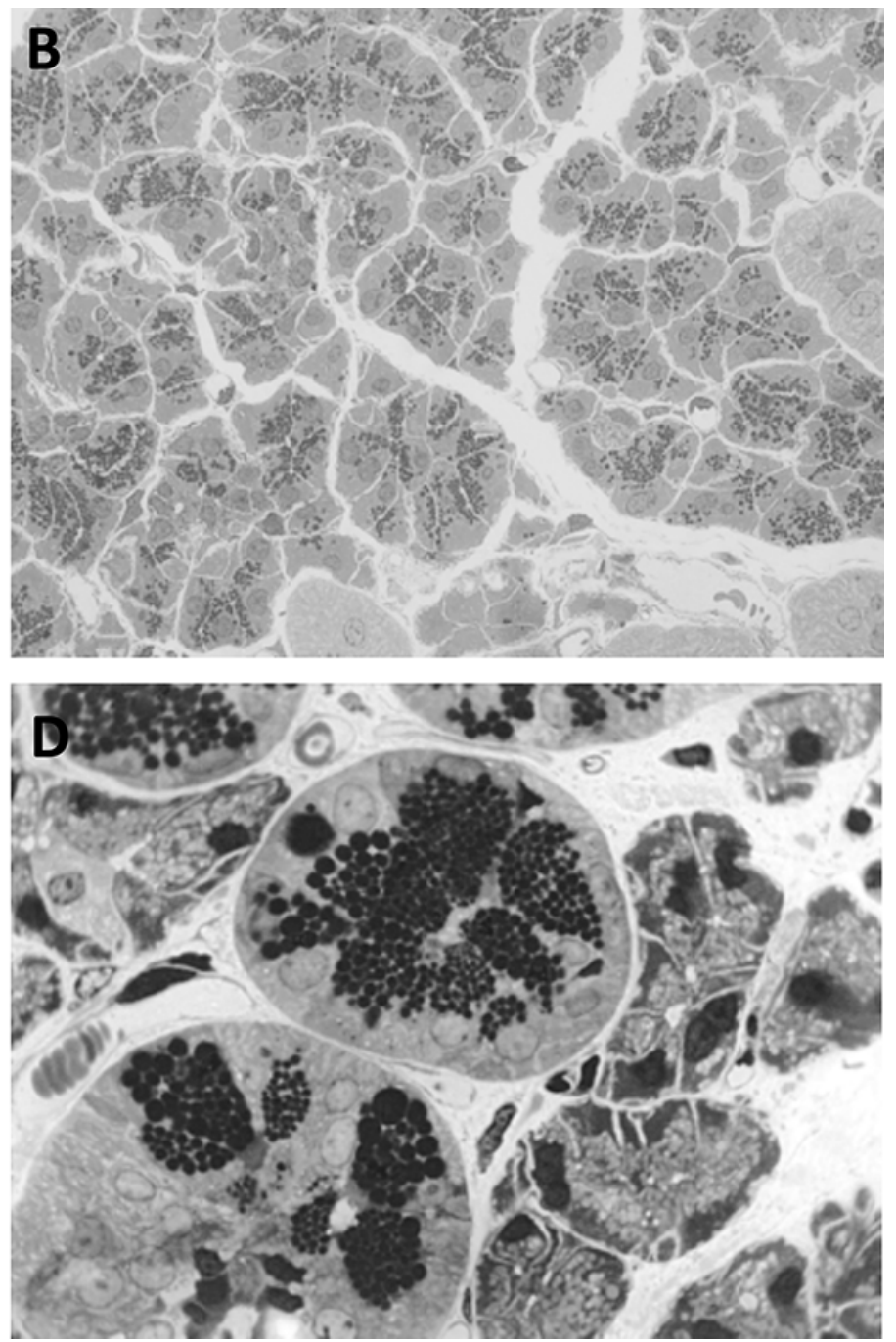

Figure 2. Optical micrographs of rat parotid gland. A. control group; B. irradiated with $4 \mathrm{~J} / \mathrm{cm} 2$ dose; C. irradiated with $8 \mathrm{~J} / \mathrm{cm} 2 \mathrm{dose}$; D. irradiated with $16 \mathrm{~J} / \mathrm{cm} 2 \mathrm{dose}$. 
With respect to the nuclear area, presented in Figure $3 \mathrm{C}$, a comparison of the control group and the $4 \mathrm{~J} /$ $\mathrm{cm}^{2}$ dose group showed no significant variation in the nuclear area, but it seems that this tends to decrease when the latter group is compared to the $8 \mathrm{~J} / \mathrm{cm}^{2}$ dose; however, in this case, the variation seems to be more significant than the previous one. On the other hand, when comparing the previous groups to the 16 $\mathrm{J} / \mathrm{cm}^{2}$ group, a noteworthy variation was observed, but unlike the previous cases, it is reflected in an increase in the area.

Finally, it was observed that the granular area in the 8 and $4 \mathrm{~J} / \mathrm{cm}^{2}$ cases decreased significantly compared to the control group. However, the samples of $16 \mathrm{~J} / \mathrm{cm}^{2}$ presented an increase in granular area compared to the other study groups, as can be seen in Figure 3D.

In terms of the number of granules, it was noted that for the samples irradiated with the 8 and $16 \mathrm{~J} / \mathrm{cm}^{2}$ doses, these decreased significantly compared to the control and $4 \mathrm{~J} / \mathrm{cm}^{2}$ cases (Figure 3E). increased significantly only with $16 \mathrm{~J} / \mathrm{cm}^{2}$ doses. This shows that, in this biological tissue type at least, this dose of low power infrared laser promotes significant changes in the cellular morphology of the glandular tissue. Previous studies using the same type of infrared laser describe morphological changes associated with the different radiation doses. For example, in the thyroid gland, $16 \mathrm{~J} / \mathrm{cm}^{2}$ doses favorably stimulate cell size. ${ }^{17}$ On the other hand, rabbit temporomandibular joint fibroblasts irradiated with a dose of $10 \mathrm{~J} / \mathrm{cm}^{2}$ showed an increase in the nuclear area, RER and cytoplasm, whereas the cell size was reduced. In this case, the authors concluded that in fibroblasts, $5 \mathrm{~J} / \mathrm{cm}^{2}$ doses are harmful to the viability and functionality of fibroblasts..$^{18,19}$ Additionally, hepatocytes irradiated with a $16 \mathrm{~J} / \mathrm{cm}^{2}$ dose showed an increase in cellular area. However, the nuclear size in that biological model did not present any significant volumetric variations [20]analgesic, and anti-inflammatory powers. It also promotes at cellular level mitochondrial ATP synthesis,
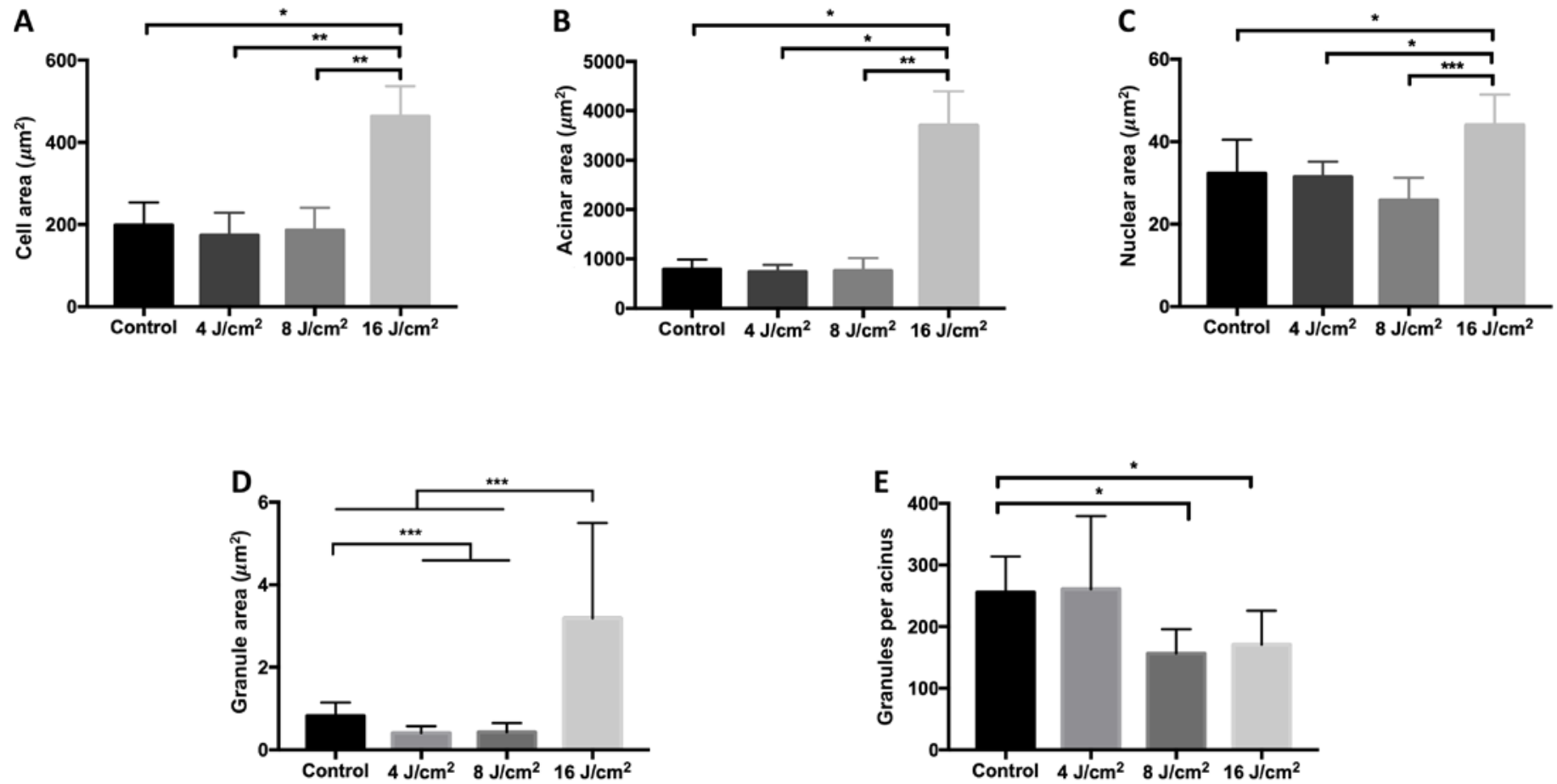

Figure 3. Morphometric analyses of the different cell structures. A. Cellular area; B. Acinar area; C. Nuclear area; D. Granular area; E. Number of granules. mean + SD; $*=\mathrm{P}<0.05 ;{ }^{* *}=\mathrm{P}<0.001 ;{ }^{* * *}=\mathrm{P}<0.0001$.

\section{Discussion}

According to the results obtained in this study, the evidence shows that the effect of increasing doses of infrared laser causes significant morphological changes in rat parotid gland, which translates into modifications in the cellular, acinar and nuclear areas as well as in the area and number of secretory granules synthesized by the cells that comprise the serous acini of the parotid gland.

It is interesting to note that the parameters associated with the cellular, acinar and nuclear areas modulates Calcium channels and activate mitotic processes by increasing DNA and protein synthesis. To determine the effective doses which stimulates rat liver protein synthesis, several samples from normal and irradiated tissues to intensities of 1, 2, 4, 8, and 16 Joules/cm 2 by 15 consecutive days were taken. These samples were later prepared and observed under transmissionE.M.(10000X. Infact, theauthorsdescribed that in 4 and $6 \mathrm{~J} / \mathrm{cm}^{2}$ doses, the volumetric fractions of mitochondria and RER - structures associated with protein synthesis - increased significantly. By 
contrast, at $16 \mathrm{~J} / \mathrm{cm}^{2}$ a reduction in the amount of RER and mitochondria was observed ${ }^{20}$ analgesic, and anti-inflammatory powers. It also promotes at cellular level mitochondrial ATP synthesis, modulates Calcium channels and activate mitotic processes by increasing DNA and protein synthesis. To determine the effective doses which stimulates rat liver protein synthesis, several samples from normal and irradiated tissues to intensities of $1,2,4,8$, and 16 Joules/cm2 by 15 consecutive days were taken. These samples were later prepared and observed under transmission E.M. (10000X, which seems to be a negative effect in terms of protein synthesis. Therefore, in hepatocytes the increase in cell size does not correspond with an increase in the volumetric fractions of structures associated with protein synthesis, such as RER and mitochondria. By contrast, 4 and $8 \mathrm{~J} / \mathrm{cm}^{2}$ doses in the parotid gland seem to interfere with the synthesis of secretory granules due to the production of granules significantly smaller than those of the control group. This is contrary to what was observed in the $16 \mathrm{~J} / \mathrm{cm}^{2}$ group, where the area of secretory granules increased significantly in size, on mean 2.5 times more than what was observed in the control group. Similar tissue effects have been observed in other studies, where chronic stimulations with isoproterenol in murine models cause hypertrophy of the parotid gland, manifesting in an increase in the size and number of secretory granules containing mainly salivary amylase and proline-rich proteins ${ }^{21,22}$ and alters the expression of several secretory proteins. We used quantitative postembedding immunogold labeling to study the cellular responses in the rat parotid gland during daily (up to 10 days. It has also been reported that dietary supplementation with grape skin extract in rats (F344/ DuCrj) promotes an increase in the size of the gland and at cellular level the synthesis of larger secretory granules, which is the result of a non-adverse adaptive effect that is reversible once the sialotrophic agent has been eliminated. ${ }^{23}$ This evidences a potential promotor effect in the synthesis of the biomolecules contained in these secretory granules. This could be answered under the dose response principle or the
Arndt-Schultz principle, which states that low doses of low power infrared laser increase or decrease the physiological functions of a cell, and as the doses or stimuli increase, a plateau is reached where the beneficial physiological effect is suppressed, obtaining an adverse physiological response (Huang, Chen, Carroll, \& Hamblin, 2009) (Ispizua, C. G., \& Manzanedo, E. S. 2012). In this context, we observed that the 4 and 8 $\mathrm{J} / \mathrm{cm}^{2}$ doses seemed to be bringing about a reduction in the biosynthesis of molecules that comprise the saliva produced by the parotid gland, such as salivary amylase, proline-rich proteins, histatins, cystatins, peroxidases or defensins. ${ }^{24}$ By contrast, the $16 \mathrm{~J} / \mathrm{cm}^{2}$ dose seems to promote the synthesis of biopolymers contained in the granules of the parotid gland cells. However, it is interesting to discuss what was observed in the cases of $8 \mathrm{~J} / \mathrm{cm}^{2}$, where there was a significant reduction in the area and number of secretory granules, i.e., the rats irradiated with $8 \mathrm{~J} / \mathrm{cm}^{2}$ had fewer and smaller granules than the non-irradiated healthy rats. This would seem to indicate that the $8 \mathrm{~J} / \mathrm{cm}^{2}$ condition has an adverse effect, which is reversed in the $16 \mathrm{~J} / \mathrm{cm}^{2}$ condition. These observations fit with the previously discussed Arndt-Schultz principle.

Finally, based on the background set out above, it is difficult for us to conclude if the infrared radiation laser at $16 \mathrm{~J} / \mathrm{cm}^{2}$ represents a dose that strengthens the physiology of a normal parotid gland. However, it is necessary to undertake future studies involving morphological parameters based on electron microscopy, which would allow us to know the different volumetric organelle fractions involved in protein synthesis. Furthermore, work is being done at the molecular level on the study of the transcribed expression levels associated with the protein synthesis of these secretory granules, as well as the identification of the presence/absence of different proteins inside these secretory granules in parotid gland cells using immunological techniques. The objective is to establish whether the different doses of infrared laser do indeed significantly affect protein synthesis, determining a potential specific tissue effect under this parameter at the cellular and molecular levels.

\section{References}

1. Borle RM, Jadhav A, Bhola N, Hingnikar P, Gaikwad P. Borle's triangle: A reliable anatomical landmark for ease of identification of facial nerve trunk during parotidectomy. J Oral Biol Craniofacial Res. 2019;

2. Standring S. Gray's Anatomy E-Book: The Anatomical Basis of Clinical Practice. Elsevier Heal. Sci. 2016.

3. Velasco I, Salinas F, Aguilar L, Gallego A, Pastrián J, Fariña R, et al. Consideraciones anatómicas en la parotidectomía: Revisión de la literatura a propósito de un caso. Int J Morphol. 2013;31:231-8.

4. Amano O, Mizobe K, Bando Y, Sakiyama K. Anatomy and histology of rodent and human major salivary glands: Overview of the Japan salivary gland society-sponsored workshop. Acta Histochem. Cytochem. 2012.

5. Cornejo R, Garrido O, Matamala F, Silva H, Mardones A, Lagos K, et al. Análisis morfométrico ultraestructural de células normales de glándula parótida de rata. Int J Morphol. 2013;31:1205-9.

6. Roa I, Del Sol M. Parotid gland comparative microscopic anatomy. Int J Morphol. 2019;37:701-5.

7. de Felice F, Tombolini M, Musella A, Marampon F, Tombolini V, Musio D. Radiation therapy and serum salivary amylase in head and neck cancer. Oncotarget. 2017;8:90496-500.

8. Peyrot des Gachons C, Breslin PAS. Salivary Amylase: Digestion and Metabolic Syndrome. Curr. Diab. Rep. 2016.

9. Lončar B, Mravak Stipetić M, Baričević M, Risović D. The effect of low-level laser therapy on salivary glands in patients with xerostomia. Photomed Laser Surg. 2011;29:171-5.

10. Cornejo R, Garrido O, Bustamante C, Muñoz M. El retículo endoplasmático liso en hepatocitos estimulados con distintas 
dosis de láser infrarrojo. Int J Morphol. 2014;

11. Bashardoust Tajali S, MacDermid JC, Houghton P, Grewal R. Effects of low power laser irradiation on bone healing in animals: A meta-analysis. J. Orthop. Surg. Res. 2010.

12. Simões A, Siqueira WL, Lamers ML, Santos MF, Eduardo CDP, Nicolau J. Laser phototherapy effect on protein metabolism parameters of rat salivary glands. Lasers Med Sci. 2009;

13. Pourzarandian A, Watanabe H, Ruwanpura SMPM, Aoki A, Ishikawa I. Effect of Low-Level Er:YAG Laser Irradiation on Cultured Human Gingival Fibroblasts. J Periodontol. 2005;

14. Uribe RC, Vargas FM, Mella HS, Onate OG. Morphometric and ultrastructural studies of the effect of infrared laser on rabbit temporo-mandibular joint fibroblasts. Brazilian Arch Biol Technol. 2009;

15. Mirzaei M, Bayat M, Mosafa N, Mohsenifar Z, Piryaei A, Farokhi $B$, et al. Effect of low-level laser therapy on skin fibroblasts of streptozotocin-diabetic rats. Photomed Laser Surg. 2007;

16. Smith NI, Fujita K, Kaneko T, Katoh K, Nakamura O, Kawata S, et al. Generation of calcium waves in living cells by pulsed-laserinduced photodisruption. Appl Phys Lett. 2001;

17. Cornejo R, Jaramillo R, Garrido O, Vergara L. Tejido tiroideo y láser infrarrojo. Un estudio morfométrico. Int J Morphol. 2017;
18. Uribe RC, Vargas FM, Mella HS, Oñate OG. Análisis morfométrico y ultraestructural del efecto del láser infrarrojo $10 \mathrm{~J} / \mathrm{cm} 2 \mathrm{sobre}$ fibroblastos de conejo. Rev Cient la Fac Ciencias Vet la Univ del Zulia. 2010;

19. Skinner SM, Gage JP, Wilce PA, Shaw RM. A preliminary study of the effects of laser radiation on collagen metabolism in cell culture. Aust Dent J. 1996;

20. Cornejo R, Matamala F, Silva H, Garrido O. Análisis morfométrico del efecto del láser infrarrojo sobre hepatocitos de rata. Int J Morphol. 2009;

21. Vugman I, Hand AR. Quantitative immunocytochemical study of secretory protein expression in parotid glands of rats chronically treated with isoproterenol. Microsc Res Tech. 1995;

22. Barka T, Burke GT. Secretory behaviour of hypertrophic and hyperplastic salivary gland. Histochem J. 1977;

23. Inoue K, Morikawa T, Matsuo S, Tamura K, Takahashi M, Yoshida M. Adaptive Parotid Gland Hypertrophy Induced by Dietary Treatment of GSE in Rats. Toxicol Pathol. 2014;

24. Gorr SU, Venkatesh SG, Darling DS. Parotid secretory granules: Crossroads of secretory pathways and protein storage. J. Dent. Res. 2005.
Received: February 11, 2021

Accepted: April 6, 2020

\section{Corresponding author}

Ricardo Cornejo

E-mail: rene.cornejo@ufrontera.cl 